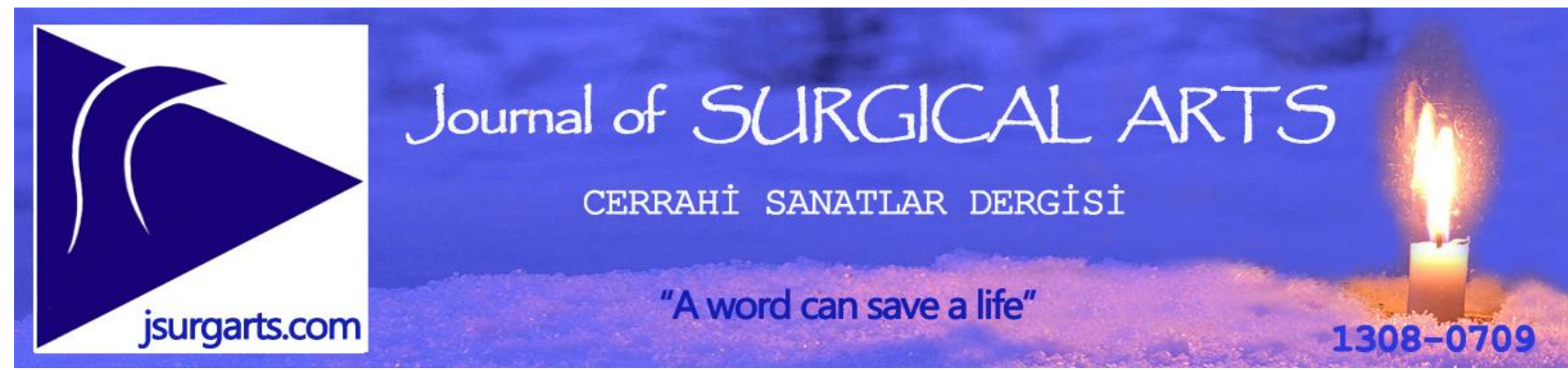

Review

\title{
Reconstruction methods in chest wall resections
}

\section{Göğüs duvarı rezeksiyonlarında rekonstrüksiyon yöntemleri}

\begin{abstract}
Hıdır Esme
Health Sciences University, Konya Training and Research Hospital, Department of Thoracic Surgery, Konya, Turkey
\end{abstract}

Address: Dr. Hidır Esme, (https://orcid.org/0000-0002-6569-8193), ㅁhesme@ hotmail.com

How to cite: Esme H. Reconstruction methods in chest wall resections. J Surg Arts: 2021;14(1):1-6. DOI: https://doi.org/10.14717/jsurgarts-210101

Received: 8/3/2020 Accepted: 01/10/2020

\section{ABSTRACT}

Chest wall defects generally result from resection of primary chest wall tumors, locally-invasive malignancies, or metastatic lesions. After an R0 chest wall resection, first skeletal stability must be established with prosthetic or bioprosthetic materials, or a combination of both. Regardless of the technique used to establish skeletal stability, soft tissue coverage of the prosthesis is necessary. The primary goals of all chest wall reconstructions are to obliterate dead space, restore chest wall rigidity, preserve pulmonary mechanic, protect intrathoracic organs and provide soft tissue coverage. In this article, our aim is to review the basic principles and indications of the chest wall resection and reconstruction, preoperative evaluation of patients, and the materials and methods used for the reconstruction.

Keywords: Chest wall, resection, reconstruction, method.

\section{ÖZET}

Göğüs duvarı defektleri genellikle primer göğüs duvarı tümörlerinin, lokal invaziv malignitelerin veya metastatik lezyonların rezeksiyonundan kaynaklanır. R0 göğüs duvarı rezeksiyonundan sonra, ilk olarak iskelet doku stabilitesi protez veya biyoprotez malzemelerle veya her ikisinin bir kombinasyonu ile oluşturulmalıdır. İskelet doku stabilitesi oluşturmak için kullanılan teknik ne olursa olsun, protezin yumuşak doku ile örtümü gereklidir. Tüm göğüs duvarı rekonstrüksiyonlarının temel hedefleri ölü alanı yok etmek, gögüs duvarı sertliğini geri kazanmak, pulmoner mekaniği muhafaza etmek, intratorasik organları korumak ve yumuşak doku ile protezin örtülmesini sağlamaktır. Bu yazıda amacımız, göğüs duvarı rezeksiyonu ve rekonstrüksiyonunun temel prensipleri, endikasyonları, hastaların preoperatif değerlendirmesi ve konstrüksiyon için kullanılan materyal ve yöntemlerin gözden geçirilmesidir.

Anahtar kelimler: Göğüs duvarı, rezeksiyon, rekonstrüksiyon, yöntem. 


\section{GíRIŞ̧}

Göğüs duvarı tümörü rezeksiyonu torasik cerrahlar için zor ameliyatlardan birisidir ve postoperatif akciğer fonksiyon bozukluğuna yol açabilir. $\mathrm{Bu}$ tür tümörlerde en iyi yaklaşım, oluşacak defektleri yeterince ön görmek ve postoperatif sonuçları optimize etmek için multidisipliner yaklaşmaktır. Tümör rezeksiyonu sonrasında, göğüs duvarının rekonstrüksiyonu, göğüs duvarının fonksiyonel yapısının yeniden kurulmasını ve ardından sağlıklı, iyi vaskülarize doku ile kaplanmasını gerektirir. $\mathrm{Bu}$ nedenle çoğu zaman yumuşak doku flepleri, sentetik veya biyoprotez materyallerle birlikte kullanılır (1). Göğüs duvarı tümörlerinin rezeksiyonu ile ilgili sonuçlar, altta yatan tümörün doğası, rezeksiyonun boyutu, rekonstrüksiyon için kullanılan materyal ve yöntemler ile ilgilidir.

Bu yazıda amacımız, göğüs duvarı rezeksiyonu ve rekonstrüksiyonunun temel prensipleri, endikasyonları, hastaların preoperatif değerlendirmesi ve konstrüksiyon için kullanılan materyal ve yöntemlerin gözden geçirilmesidir.

Göğüs duvarı rezeksiyonlarının endikasyonları

Göğüs duvarı rezeksiyonlarının en yaygın endikasyonları, primer veya metastatik göğüs duvarı tümörleri, meme ve akciğer kanserinin invazyonları, radyasyon nekrozu, konjenital defektler, travmalar ve sternotomi veya torakotomi sonrası ortaya çıkan yara enfeksiyonlarıdır. Nadiren benign göğüs duvarı tümörlerine bağlı göğüs duvarı rezeksiyonu ve rekonstrüksiyonu uygulanmaktadır. Klinikte sıklıkla primer göğüs duvarı tümörleri, akciğer ve meme kanseri gibi malignitelerin toraks duvarını invaze etmeleri sonucunda karşımıza çıkmaktadır. Göğüs duvarının primer tümörleri, rezeksiyonların yaklaşık \%30'unu oluşturmaktadır (2).

Benign göğüs duvarı tümörleri nadiren göğüs duvarı rezeksiyonu sonrası rekonstrüksiyon gerektirir. Kondroma gögüus duvarı benign tümörlerinin \%15 ile 20'sini oluşturur (3). Osteokondroma kostokondral bileşkede sık görülür. Rezeksiyonda amaç malign transformasyon riskini minimalize etmekle birlikte kitleye eşlik eden gögüs duvarı ağrısını ortadan kaldırmaktır. Fibröz displazi, eozinofilik granuloma, lenfanjioma ve desmoid tümör nadiren gögüs duvar rezeksiyonu ve rekonstrüksiyonu gerektiren diğer benign tümörlerdir.

Malign göğüs duvarı tümörleri sıklıkla hızlı büyür ve benign tümörlere göre daha büyük kitlelerle prezente olur. Kondrosarkoma göğ̈̈s duvarının en sık malignitesidir ve primer malignitelerin yaklaşık \%30'nu oluşturur (4). Kondrosarkoma karekteristik olarak ağrılı, sert, fikse kitle olarak görülür ve hastaların \%10'nunda senkron akciğer metastazı görülür (5). Bunlar tipik olarak anterior gögüs duvarında (kostokondral bileşke veya sternum) lokalizedirler ve dejenere kondromalardan kaynaklanabilirler. Cerrahi sınırı negatif olan cerrahi rezeksiyon temel tedavidir ve lokal nüksün en iyi prediktörüdür. Definitif tedavi en az $4 \mathrm{~cm}$ negatif cerrahi sınır gerektirir ve bu hastaların çoğunda küratiftir. Lokal rekürrens negatif cerrah sınırlarda \%10 iken pozitif olanlarda $\% 75$ tir (6). Kondrosarkom genellikle radyoterapi ve kemoterapiye duyarsızdır. Yüksek doz radyoterapi sinırlı etkiye sahiptir (7).

Osteosarkomlar malign göğüs duvarı tümörlerinin \%10-15'ini oluşturur ve genellikle kaburga, skapula ve klavikulalarda görülür (Resim 1). Ewing sarkom grubu tümörler, Ewing sarkomu, Askin tümörü ve primitif nöroektodermal tümörü içerir ve göğüs duvarı malignitelerinin yüzde 5 ila 10'unu oluşturur (8).

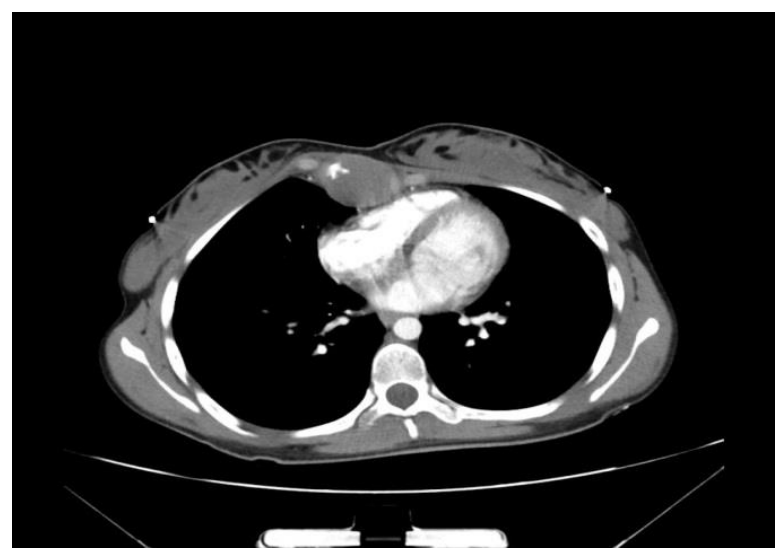

Resim 1: Sternum kaynaklı kondrosarkom olgusunun bilgisayarlı tomografi görüntüsü

Yumuşak doku sarkomları göğüs duvarı primer malign tümörlerinin yaklaşık yüzde 45 'ini temsil eder ve en sık görülen primer malign yumuşak doku lezyonlarıdır. Yumuşak doku sarkomlarının en yaygın örnekleri malign fibröz histiyositom ve rabdomiyosarkomdir. $\mathrm{Bu}$ tümörler fasiyal düzlemler boyunca ve kas lifleri arasında yayılabilir ve rezeksiyon sonrası yüksek rekürrens oranları ile sonuçlanır, beş yıllık sağkalım oranları yüzde 60 ila 75 arasındadır $(9,10)$. Diğer malign yumuşak doku tümörleri arasında liposarkomlar ve nörofibrosarkomlar yer alır. Geniş lokal eksizyon hastaların çoğunda tek tedavi seçeneğidir.

Meme ve akciğer malignitelerinde lokal invazyonlar ortaya çıkabilir veya göğüs duvarına metastaz yapabilirler. Lokal hastalık kontrolü için cerrahi rezeksiyon gerekebilir (11). Bu durumlarda, metastatik kanserler için göğüs duvarı ve sternal rezeksiyon ağrıyı hafifletebilir ve tümöre bağlı ülserasyonların ortadan kaldırılmasını sağlar. Soliter iskelet metastazı gibi sınırlı hastalığa sahip olan hastalar, cerrahi rezeksiyona uygundur.

Meme, akciğer veya lenfoma tedavisini takiben göğüs duvarının radyasyona bağlı malign tümörleri nadirdir. Gögüs duvarı radyoterapisi öyküsü olan hastaların yaklaşık yüzde 6'sında göğüs duvarı tümörleri ortaya çıkar (12). Geniş lokal eksizyon tercih edilen tedavidir. Radyotrapiden sonra ortaya çıkan tümörler cerrahi olarak tedavi edildiğinde diğer tümörlerle benzer bir prognoza sahiptir, ancak radyoterapiye daha fazla dirençlidir. 
Preoperatif değerlendirme ve hazırlık

Göğüs duvarı tümörleri asemptomatik olabilir. Semptomatik olduğunda ağrı en yaygın semptomdur ve kemik invazyonunun bir işareti olabilir. Kapsamlı bir fizik muayene ile hastanın genel durumun, göğsün duvarı kitlesinin büyüklüğü ve etraf dokulara fiksasyonu, herhangi bir göğüs duvarı anormalliğinin kapsamı ve yeri ve güvenilir kas fleplerinin çekilmesine engel olabilecek yaraların varlığı mutlaka değerlendirilmelidir. Örneğin, önceki bir torakotomi insizyonu flep çevirme için gerekli olan kan desteğini bozmuş olabilir. Hastanın düşünülen rezeksiyona adaylığını belirlemek ve postoperatif komplikasyonları ön görmek için ameliyat öncesi rutin laboratuar testlerine ilave olarak solunum fonksiyon testleri yapılmalıdır. Primer akciğer tümörü olan bazı hastalarda, kilo kaybı ve yetersiz beslenmeye bağlı yara iyleşmesinde gecikme ve postoperatif komplikasyonlar daha sık görülebilir. Rezeksiyon öncesi hastanın medikal durumu, anormal biyokimyasal parametreleri ve malnütrisyonu düzeltilmelidir.

Göğüs duvarı rezeksiyonu planlanırken immünosupresif tedaviler, radyoterapi öyküsü veya planl gelecekteki radyoterapi ve geçirilmiş göğüs cerrahi işlemleri dikkate alınmalıdır, çünkü bunlar yara iyileşmesini ve rekonstrüksiyon seçeneklerini etkileyebilir. Neoadjuvan kemoterapi osteosarkom, rabdomiyosarkom, Ewing sarkomu ve diğer küçük hücreli sarkomların tedavisinde etkilidir. Palyatif rezeksiyon uygulanan veya cerrahi sınır pozitif hastalarda adjuvan radyoterapi gerekebilir.

\section{Radyolojik değerlendirme}

Preoperatif görüntüleme, özellikle kontrastlı bilgisayarlı tomografi (BT), tümörün boyutunu tanımlamak, lokal vaskülariteyi, rezeksiyon sonrası defektin yerini ve genişliğini tahmin etmek için önemlidir. Göğüs radyografisi, BT, manyetik rezonans görüntüleme (MRG) ve pozitron emisyon tomografisi (PET), göğüs duvarı tümörünün değerlendirilmesinde yararlı olacaktır (13). Kalsifikasyon, ossifikasyon veya kemik destrüksiyonu malignitenin belirtileridir ve BT incelemesinde veya göğüs grafisinde görülebilir. PET/BT rejyonel lenf nodları tutulumunu ve metastatik hastalık varlığını göstermede yardımcı olabilir. PET/BT hem başlangıç evrelemesi için hem de sarkomlarda tedavi yanıtını değerlendirmede tek başına BT'den daha değerlidir (14).

\section{Doku tanis1}

Tanısal doku biyopsisi, geniş rezeksiyon ve rekonstrüksiyon gerektiren vakalarda temel bir işlemdir. Ayrıca bazı göğüs duvarı tümörlerinin tedavisi, cerrahi olmayıp medikal tedavi olduğundan tanısal doku biyopsisi gerektirir. Bunlar soliter plazmositoma, Ewing sarkomu, lenfoma ve metastatik tümörlerdir. Önerilen biyopsi tekniği “tru-cut", eksizyonel veya insizyonel biyopsidir. Bunun nedeni morfolojik ve immunohistokimyasal doku tanısı ve moleküler genetik çalışmalar için yeterli örneklem sağlayabilmektir. İnce iğne aspirasyon biyopsileri malign tümör tipini belirlemede yetersiz kalmaktadır. Eksizyonel biyopsi tru-cut iğne biyopsilerinin tanısal olmadığı, tümörün $5 \mathrm{~cm}$ 'den küçük, lezyonun benign olma olasılığı taşıdığ 1 olgularda endikedir. $\mathrm{Bu}$ olgularda tümör etrafında $2 \mathrm{~cm}$ 'lik sınır bırakmak yeterlidir. Ínsizyonel biyopsi ise tümör 5 cm'den büyük ve aksilla gibi zor bir bölgede ise veya neoadjuvan tedavi gerekli ise endikedir (2).

\section{Plastik cerrahi konsültasyonu}

Göğüs duvarı rezeksiyonlarına, hem göğüs cerrahisi hem de plastik cerrahın ameliyat öncesi birlikte değerlendirmesi ile multidisipliner bir şekilde yaklaşmak akıllıca olacaktır. Yaygın olarak kullanılan rotasyon fleplerinin çoğu basittir ve torasik cerrah tarafindan yapılabilirken, kompleks rekonstrüksiyonlar genellikle rekonstrüktif cerrahın uzmanlığını gerektirir.

\section{GÖĞÜS DUVARI REZEKSIYYONU}

Göğüs duvarı rezeksiyonu gerektiren hastaların tedavisinde cerrahi rezeksiyonun 3 temel kuralı göz önünde bulundurulmalıdır. Birincisi, geride tümöral doku kalmayacak şekilde geniş rezeksiyon yapılmalıdır. İkincisi, geniş göğüs duvarı rezeksiyonlarında yelken göğüs oluşumunu engellemek için rijit gögüs duvarı oluşturulacak şekilde rekonstrüksiyon uygulanmalıdır. Üçüncüsü, sağlıklı yumuşak doku ile protezin örtülmesi enfeksiyon oluşumunu engellemek için esastır (15-19).

Gögüs duvarının malign tümörleri için yapılan göğüs duvarı rezeksiyonu sonrası sağkalım tümörün histolojisi, cerrahi sınırların tümör negatif olması ve uzak metastaz varlığına bağlıdır (20). Göğüs duvarının malign tümörlerinde geniş cerrahi rezeksiyon yapılması gerekmektedir. $\mathrm{Bu}$ amaçla tümörden makroskopik olarak en az $4 \mathrm{~cm}$ mesafeden, alttan ve üstten birer sağlam kot çıkarılarak rezeksiyon uygulanması gerekmektedir. Rekonstrüksiyondan önce cerrahi sınırlardan frozen mutlaka gönderilmeli, pozitif olması durumunda rezeksiyon genişletilmelidir. Göğüs duvarının malign tümörleri için yapılan göğüs duvarı rezeksiyonu sonrası 5 yıllık sağkalım ortalama $\% 50$ olarak rapor edilmiştir. Lokal nüks olan meme kanserlerinde rezeksiyon sonras1 5 yillık sağkalım \%34-58 olarak rapor edilmiştir (20).

Küratif bir rezeksiyon için tümör anblok ve yeterli negatif cerrahi sınır sağlanarak çıkarılmalıdır. Anblok rezeksiyon tümör etrafindaki cilt ve yumuşak dokuyu, tutulu kot veya sternumu, akciğer, diyafragma ve perikard gibi invazyon olan dokuları da içermelidir (2). Cerrahi sınır uzaklığı konusunda bazı çalışmalarda 4 cm'lik bir uzunluk verilirken bazı çalışmalarda cerrahi sınır için bir uzaklık verilmemektedir (21-26). Mayo Kliniğinin tüm primer toraks duvarı tümörlerini içeren çalışmasında 5 yıllık hastalıksız sağkalım cerrahi sınırı $4 \mathrm{~cm}$ ve üzeri olanlarda $(\mathrm{n}=22) \% 56$ iken $2-4 \mathrm{~cm}$ olanlarda $(n=49) \% 29$ bulunmuştur (23). Yakın zamanda yapılan bir başka çalışmada ise $2 \mathrm{~cm}$ ve altı cerrahi sınıra sahip olup cerrahi sinırı temiz olan hastalar $(\mathrm{n}=44)$ ile geniş cerrahi sınıra $(>2 \mathrm{~cm}$ olanlar) sahip hastaların $(\mathrm{n}=26) 5$ yıllık sağkalımlarında fark saptanmamıştır (21). Burada cerrahi sınır genişliğinden çok komplet rezeksiyonun daha önemli olduğu vurgulanabi- 
lir. Bununla birlikte agresif, yüksek grade veya infiltratif maligniteler için genellikle $4 \mathrm{~cm}$ negatif cerrahi sınır ile geniş lokal eksizyon endikedir. Ancak bazen anatomik lokalizasyon ve çevre damarsal yapılar buna izin vermeyebilir. Benign ve düşük grade maligniteler için 1 ila $2 \mathrm{~cm}$ 'lik negatif cerrahi sinır genellikle yeterlidir

\section{GÖĞÜS DUVARI REKONSTRÜKSIYONU}

İlk göğüs duvarı rekonstrüksiyonu 1906 yılında Tensini tarafından anterior göğüs duvarı defektinin pediküllü latisimus dorsi flebi kullanılarak kapatılması olarak tanımlanmıştır (27). O zamandan bu yana göğüs duvarı rekonstrüksiyonunda önemli ilerlemeler kaydedilmiștir. Tüm göğüs duvarı rekonstrüksiyonlarının temel hedefleri ölü alanı yok etmek, göğüs duvarı sertliğini geri kazanmak, pulmoner mekaniği muhafaza etmek, intratorasik organları korumak ve yumuşak doku ile protezin örtülmesini sağlamaktır $(28,29)$. Bundan dolayı göğüs cerrahisi, plastik cerrahisinin yanı sıra tıbbi ve radyasyon onkolojisini içeren multidisipliner yaklaşım esastır.

Büyük göğüs duvarı tümörleri, rezeksiyon ve sadece kas fleplerinin çekilmesiyle tedavi edilebilir (30). Ancak bu hastalarda genellikle göğüs duvarı instabilitesinden dolayı solunum ve yoğun bakım desteğine ihtiyaç duyulur. Birçok yazar yumuşak doku flepleri yanında göğüs duvarının rijit stabilizasyonunun ventilatör bağımlılığını ve hastanede kalış süresini azatlığını bildirmiştir. Sadece kas flepleriyle kapatılan defektlerle karşılaştırıldığında postoperatif $\mathrm{PaO} 2$ ve akciğer fonksiyonlarında anlamlı düzelme saptandığı bildirilmiştir (31-33). Birçok sentetik, biyolojik metalik materyal göğüs duvarı defektlerini rekonstrükte etmek için kullanılabilmektedir, fakat her bir prostetik materyalin avantajları ve dezavantajları vardır. Hiç birinin diğerlerinden açıkça üstün olduğu kanıtlanamamıştır $(30,32)$. Hangi materyalin kullanılacağ 1 konusunda en önemli kriter cerrahın tercihi ve tecrübesidir.

Vicryl (poliglaktin), Prolen (polipropilen), Marlex (örgülü polipropilen) ve Gore-Tex (polytetrafluoroethylene) sik kullanılan rijit olmayan alloplastik materyallerdir $(16,32)$. İskelet rekonstrüksiyonu için kullanılan greftler otojen ve sentetik olarak ikiye ayrılabilir. Otojen greftler; kosta, iliyak kemik veya fibuladan vasküler veya avasküler kemik grefti şeklinde olabilir. Bunların sonuçları oldukça iyi olmakla beraber ek morbidite oluşturduğu için birçok merkezde sentetik greftler sıklıkla kullanılmaktadır. Metilmetakrilat ve titanyum plakları en sik kullanılan rijit sentetik greftlerdir. Rijit sentetik greftler ile rijit olmayan alloplastik materyallerin birlikte kullanımı son zamanlarda tercih edilen bir yöntemdir.

\section{Metilmetakrilat ve prolen meş}

Göğüs duvarı defektinin kapatılmasında birçok yöntem başarıyla kullanılmıştır. 1972 den beri 2 tabaka marlex meş arasında metilmetakrilattan oluşan greft özellikle parsiyel sternum rezeksiyonunu gerektiren büyük anterolateral göğüs duvarı defektlerinde kullanımı giderek artmıştır (16-19,34,35). Bu teknik normal spontan solunum ve öksürük için yeterli stabiliteyi sağlayan ve kozmetik olarak kabul edilebilir ideal rekonstruksiyon kriterlerini sağlayan bir yöntemdir (Resim 2 ve 3). Ayrıca bu yöntem, göğsün şekline göre proteze uygun bir şekil verilerek defektin kapatılmasına olanak sağlayan bir yöntemdir. Metilmetakrilat kullanılan hastalarda yabancı cisim reaksiyonu veya septik komplikasyonlarda artış bildirilmemiştir (20). Polyprolen meşin diğer meşlere göre rejeksiyon ve enfeksiyon açısından önemli avantajlara sahip olduğu bildirilmiştir (32).

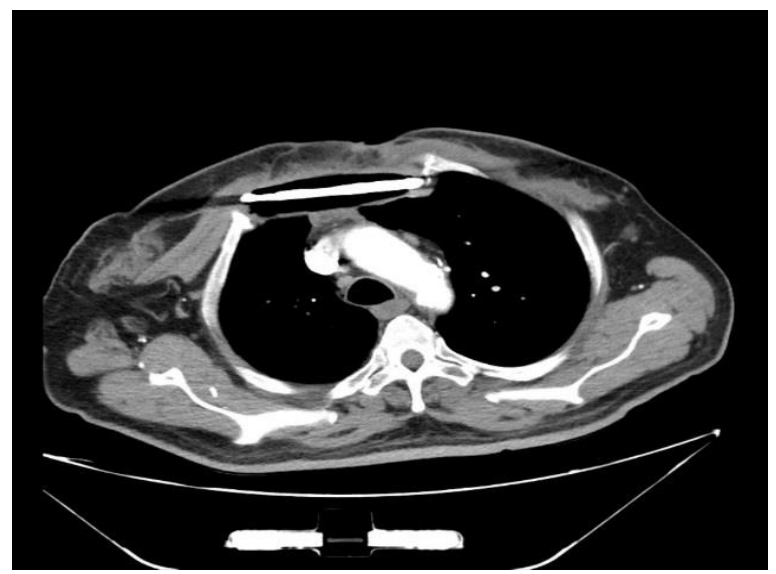

Resim 2: Sternum korpusu, sağ 3, 4 ve 5. Kot parsiyel rezeksiyonu sonrası metilmetakrilat ve prolen meş ile yapılan sandaviç greftin radyolojik görüntüsü.

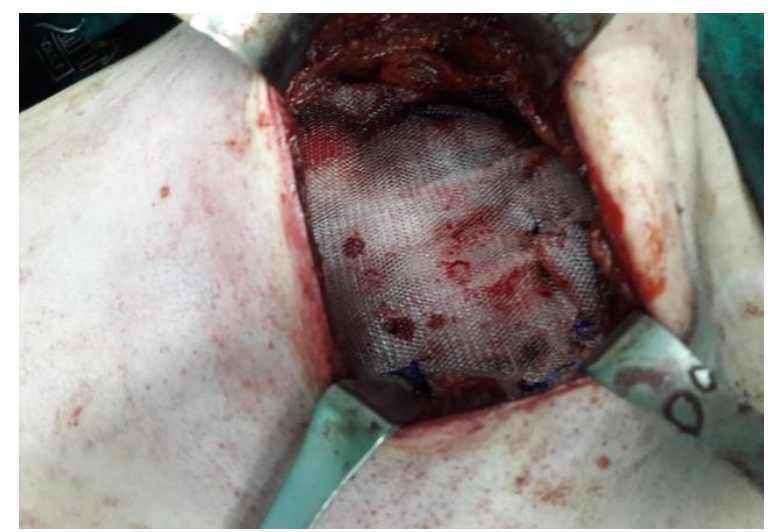

Resim 3: Metilmetakrilat ve prolen meşten oluşan sandaviç greftin ameliyat görüntüsü.

Le Roux ve Sherma (36) ideal bir prostetik materyelin özelliklerini şöyle belirlemişlerdir: (1) paradoksal hareketi önleyecek kadar rijit; (2) enfeksiyon riskini azaltan ve fibröz dokunun gelişimine izin veren yapıda; (3) operasyon sırasında uygun şeklin verilebileceği esneklik; ve (4) daha iyi bir takip yapabilmek için radyolusens olması. Bu özellikler açısından baktığımızda metilmetakrilat ve prolen meşten yapılan sandaviç greftler yeterince rijidite sağlayabilen, radyolusent ve donma anına kadar şekil verilebilen protezlerdir. $\mathrm{Bu}$ greftlerin en önemli komplikasyonu \%20 oranında metilmetakrilat kırılmaları ve enfeksiyonlardır $(33,34)$. Bu sentetik materyaller $\% 5$ oranında çıkarılmak zorunda kalınmaktadır. Yaygın görüş enfeksiyon riskininin 
sandeviç greftin yumuşak doku ile örtülmesi ile azaltılabileceğidir $(29,34,37,38)$.

Titanyum plak ve prolen meş

Son yıllarda titanyum barlar da rekonstrüksiyonda sıklıkla kullanılmaktadır (Resim 3 ve 4). Titanyum bar korozyona dirençli, hafif ve MRG ile uyumludur. Titanyum çelik kadar dayanıklı fakat \%40 daha hafiftir, aleminyumdan \%60 daha fazla ağırdır ancak iki katı daha mukavemetlidir (39). Sternum ve geniş kosta defektlerinde kullanılabilirler. Bar fraktürleri, bar dislokasyonları ve göğüs ağrısı en sık komplikasyonlardır. Plak fraktürleri oranı bazı çalışmalarda \%0 ile 11 arasında verilmiştir. Titanyum plak dislokasyonu genellikle kaburga kalınlığı ile plağı kaburgaya tespit eden vidaların uzunluğu arasındaki uyumsuzluğa bağlıdır (34).

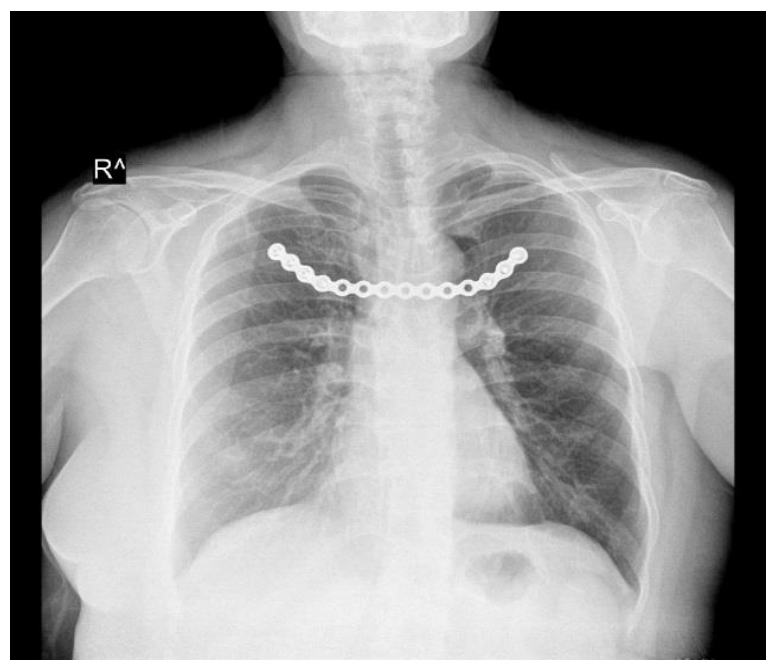

Resim 4: Sternum rezeksiyonu sonrası titanyum plak ve prolen meşin radyolojik görüntüsü.

Yapılan hayvan ve insan çalışmalarında, göğüs duvarının rekonstrüksiyonunda kullanılan materyaller arasında titanyum bakteriyel kolonizasyona en dirençli olandır (40). Lens ve arkadaşları (41) göğüs duvarı rezeksiyonu ve rekonstrüksiyonu yaptıkları 220 hastanın 41 'inde (\%18) yara yeri enfeksiyonu saptamışlardır. Berthet ve arkadaşları enfekte gögüs duvarı lezyonlarında bile rezeksiyon sonrası titanyum plak ile rekonstrüksiyon uyguladığ 1 hastalarda güzel sonuçlar bildirmiştir (40).

Yumuşak doku rekonstrüksiyonu

İskelet rezeksiyonu sonrasında ikinci aşama yumuşak doku rekonstrüksiyonudur. Gögüs duvarı rekonstrüksiyonu ile birlikte çevre yumuşak doku ile protezin örtülmesi major rezeksiyon sonrası gögüs duvarı defektlerinin yaklaşımında temel prensiptir. Her olguda uygulanmasına gerek yoktur. Ancak stabiliteyi sağlamak, enfeksiyonu önlemek, protezin direk cilde bask1sından sakınmak ve daha kozmetik sonuçlar elde etmek için yapılması önerilmektedir.

Özellikle anterior ve geniş defektlerde kas transpozisyonu şeklinde uygulanmaktadır (42). Yumu- şak doku rekonstrüksiyonu cilt kaydırmaları, saplı miyokütanöz flepler veya serbest miyokütanöz fleplerle sağlanabilir. Günümüz cerrahisinde en s1k kullanılan miyokütanöz flepler pektoralis major, latissimus dorsi ve serratus anterior greftleridir. Radikal yapılan tam kat ve geniş rezeksiyonlarda kas transpozisyonu da planlanıyorsa plastik cerrahlar ile iş birliğinde olunmalıdır.

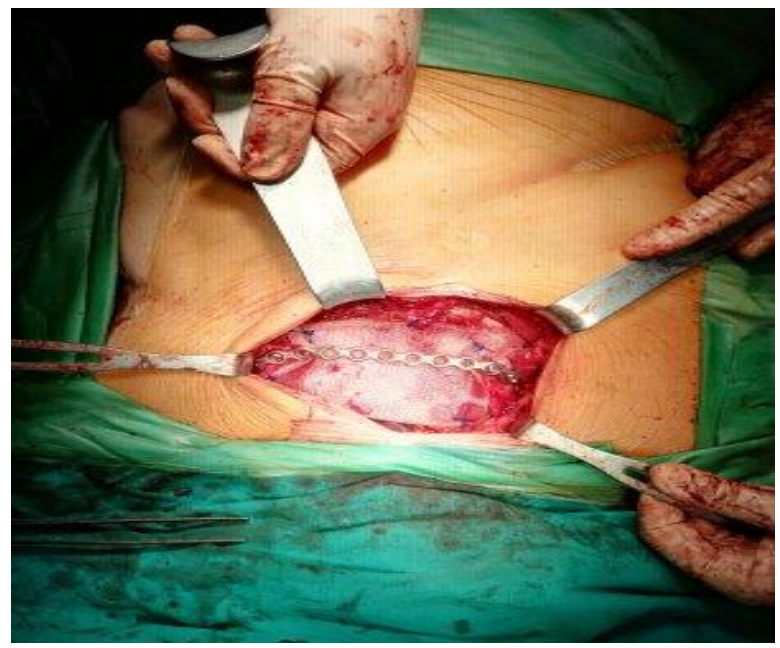

Resim 5: Titanyum plak ve prolen meş ile rekonstrüksiyonun ameliyat görüntüsü.

\section{KAYNAKLAR}

1. Sanna S, Brandolini J, Pardolesi A, Argnani D, Mengozzi M, Dell'Amore A, Solli P. Materials and techniques in chest wall reconstruction: a review. J Vis Surg. 2017;3:95.

2. Kaya ŞÖ, Usluer O, Yakut FC. Göğüs duvarı rezeksiyon ve rekonstrüksiyonu. Turkiye Klinikleri J Thor Surg-Special Topics 2018;9:155- 9.

3. Shah AA, D'Amico TA. Primary chest wall tumors. J Am Coll Surg 2010;210:360.

4. Somers J, Faber LP. Chondroma and chondrosarcoma. Semin Thorac Cardiovasc Surg 1999;11:270.

5. Tateishi U, Gladish GW, Kusumoto M, et al. Chest wall tumors: radiologic findings and pathologic correlation: part 2. Malignant tumors. Radiographics 2003;23:1491

6. Fong YC, Pairolero PC, Sim FH, et al. Chondrosarcoma of the chest wall: a retrospective clinical analysis. Clin Orthop Relat Res 2004;9:184.

7. Kawaguchi S, Weiss I, Lin PP, et al. Radiation therapy is associated with fewer recurrences in mesenchymal chondrosarcoma. Clin Orthop Relat Res 2014;472:856.

8. Gallo AE, Coady MA. Chest wall tumors. In: Johns Hopkins Manual of Cardiothoracic Surgery, Yuh DD, Vricella LA, Baumgartner WA (Eds), McGraw-Hill Professional, New York, 2006, p:80.

9. Saenz NC, Ghavimi F, Gerald W, et al. Chest wall rhabdomyosarcoma. Cancer 1997;80:1513.

10. Hayes-Jordan A, Stoner JA, Anderson JR, et al. The impact of surgical excision in chest wall rhab- 
do-myosarcoma: a report from the Children's Oncology Group. J Pediatr Surg 2008;43:831.

11. Haraguchi S, Hioki M, Takushima M, et al. Metastatic chest wall tumor suspected to be of lung origin by immunoreactivity for cytokeratin 7 and 20 . Jpn J Thorac Cardiovasc Surg 2006;54:132.

12. Schwarz RE, Burt M. Radiation-associated malignant tumors of the chest wall. Ann Surg Oncol 1996;3:387.

13. Lee TJ, Collins J. MR imaging evaluation of disorders of the chest wall. Magn Reson Imaging Clin N Am 2008; 16:355.

14. Piperkova E, Mikhaeil M, Mousavi A, et al. Impact of PET and CT in PET/CT studies for staging and evaluating treatment response in bone and soft tissue sarcomas. Clin Nucl Med 2009;34:146.

15. McCormack P, Bains MS, Beattie EJ Jr, Martini N. New trends in skeletal reconstruction after resection of chest wall tumors. Ann Thorac Surg 1981;31:45-52.

16. Arnold PG, Pairolero PC. Chest-wall reconstruction: An account of 500 consecutive patients. Plast Reconstr Surg 1996;98:804-10.

17. Mansour KA, Thourani VH, Losken A, Reeves JG, Miller JI Jr, Carlson GW, et al. Chest wall resections and reconstruction: A 25-year experien-ce. Ann Thorac Surg 2002;73:1720-6.

18. Banic A, Ris HB, Erni D, Striffeler H. Free latissimus dorsi flaps for chest wall repair after complete resection of infected sternum. Ann Thorac Surg 1995;60:1028-32.

19. Kroll SS, Walsh G, Ryan B, King RC. Risks and benefits of using marlex mesh in chest wall reconstruction. Ann Plast Surg 1993;31:303-6.

20. Incarbone M, Pastorino U. Surgical treatment of chest wall tumors. World J Surg 2001;25:218-30.

21. Widhe B, Bauer HC; Scandinavian Sarcoma Group. Surgical treatment is decisive for outcome in chondrosarcoma of the chest wall: a populationbased Scandinavian Sarcoma Group study of 106 patient. J Thorac Cardiovas Surg 2009;137:610- 4.

22. David EA, Marshall MB. Review of chest wall tumors: a diagnostic, therapeutic, and reconstructive challenge. Semin Plast Surg 2011;25:16- 24.

23. King RM, Pairolero PC, Trastek VF, Piehler JM, Payne WS, Bernatz PE. Primary chest wall tumors: factors affecting survival. Ann Thorac Surg 1986;41:597-601.

24. Burt M, Fulton M, Wessner DS, et al. Primary bony and cartilaginous sarcomas of chest wall: results of therapy. Ann Thorac Surg 1992;54:226-32.

25. McAfee MK, Pairolero PC, Bergstralh EJ. Chondrosarcoma of the chest wall: factors affecting survival. Ann Thorac Surg 1985;40:535-41.

26. Walsh GL, Davis BM, Swisher SG, et al. A single institutional multidisciplinary approach to primary sarcomas involving the chest wall requiring fullthickness resections. J Thorac Cardiovasc Surg 2001;121:48-60.
27. Tensini I. Sopra il mio nuovo processo di amputazione della mammella. Gazetta Med Ital 1906;57: 141-2.

28. Seder CW, Rocco G. Chest wall reconstruction after extended resection. J Thorac Dis 2016;8:86371.

29. Tukiainen E, Popov P, Asko-Seljavaara S. Microvascular reconstructions of full-thickness oncological chest wall defects. Ann Surg 2003;238:794801.

30. Weyant MJ, Bains MS, Venkatraman E, et al. Results of chest wall resection and reconstruction with and without rigid prosthesis. Ann Thorac Surg 2006;81:279-85

31. Petrella F, Radice D, Borri A, et al. Chest wall resection and reconstruction for locally recurrent breast cancer: From technical aspects to biological assessment. Surgeon 2016;14:26-32.

32. Deschamps C, Tirnaksiz BM, Darbandi R, et al. Early and long-term results of prosthetic chest wall recontruction. J Thorac Cardiovasc Surg 1999;117: 588-91.

33. Ng CS. Recent and Future Developments in Chest Wall Reconstruction. Semin Thorac Cardiovasc Surg 2015;27(2):234-9.

34. Niwa H, Yamakawa Y, Kobayashi S, Kasugai T, Masaoka A, Mizuno T. Preservation of pulmonary function by chest wallreconstruction. Nippon Geka Gakkai Zasshi. 1991;92:1359-62.

35. Graeber GM, Langenfeld J. Chest wall resection and reconstruction. In: Franco KL, Putman JR, eds. Advanced therapy in thoracic surgery. London: BC Decker. 1998;175-85.

36. le Roux BT, Shama DM. Resection of tumors of the chest wall. Curr Probl Surg 1983;20:345-86.

37. 37. Ferraro P, Cugno S, Liberman M, et al. Princip-les of chest wall resection and reconstruction. Thorac Surg Clin 2010;20:465-73.

38. Thomas PA, Brouchet L. Prosthetic reconstruction of the chest wall. Thorac Surg Clin 2010;20:551-8.

39. Tamburini N, Grossi W, Sanna S, Campisi A, Londero F, Maniscalco P, Dolci G, Quarantotto F, Daddi N, Morelli A, Cavallesco G, Dell'Amore A. Chest wall reconstruction using a new titanyum mesh: a multicenters experience. J Thorac Dis. 2019;11:3459-66.

40. Lans TE, van der Pol C, Wouters MW, et al. Comp-lications in wound healing after chest wall resection in cancer patients; a multivariate analysis of 220 patients. J Thorac Oncol 2009;4:639-43.

41. Berthet JP, Solovei L, Tiffet O, et al. Chest-wall reconstruction in case of infection of the operative site: is there any interest in titanyum rib osteosynthesis? Eur J Cardiothorac Surg 2013;44:866-74.

42. Citak N, Celikten A, Metin M, Pekcolaklar A, Gürses A. Radical resection of a giant recurrent chondrosarcoma of the anterior chest wall. Gen Thorac Cardiovasc Surg 2011;59(7):512-4. 